\title{
Hubungan Kecemasan Matematika dan Digital Storytelling Terhadap Math Literacy Pada Siswa Sekolah Menengah Pertama dalam Pembelajaran Matematika Pada Kelas Virtual
}

\author{
Elsa Nabilah \\ Prodi Pendidikan Matematika, Fakultas Keguruan dan Ilmu Pendidikan, Universitas Muhammadiyah Prof. Dr. Hamka, \\ Jl. Tanah Merdeka No. 20 RT.11/RW.2, Rambutan, Pasar Rebo, Jakarta Timur, DKI Jakarta 13830, Indonesia \\ khoerul.umam@uhamka.ac.id
}

\begin{abstract}
This research aims to acknowledge the relation between mathematics anxiety and digital storytelling on the math literacy of junior high students in learning mathematics in virtual class. This research uses a quantitative survey method chosen by the researcher to achieve the research objective. The samples of this research are the 300 junior high students that reside in Jakarta, Bogor, Depok, Tangerang, dan Bekasi. The data collection technique is done using questionnaires. The data analysis is done using the product moment correlation method and the multiple linear regression method, which consists of mathematics anxiety $(X 1)$ and digital storytelling $(X 2)$ as the independent variables and math literacy $(Y)$ as the dependent variable. Based on the data analysis result, the findings show that (1) there is a relation with negative direction and moderate relation degree between mathematics anxiety and math literacy, (2) there is a relation with positive direction and strong relation degree between digital storytelling and math literacy, (3) there is a positive relation between mathematics anxiety and digital storytelling on the math literacy by $66 \%$. For further research, the researcher should not only use questionnaires for data collection but may create a project in class. Keywords: Mathematics Anxiety, Digital Storytelling, Math Literacy, Mathematics Learning
\end{abstract}

\begin{abstract}
Abstrak
Pengkajian ini bertujuan untuk mendeteksi hubungan kecemasan matematika serta digital storytelling pada math literacy pada siswa sekolah menengah pertama dalam pembelajaran matematika di kelas virtual. Pengkajian ini menggunakan cara survey kuantitaif yang dipilih oleh peneliti untuk mencapai tujuan penelitian. Sampel dalam pengkajian ini ialah 300 siswa sekolah menengah pertama yang berwilayah di Jakarta, Bogor, Depok, Tangerang serta Bekasi. Teknik pengumpulan data dikerjakan memakai kuesioner. Analisis data dikerjakan memakai metode korelasi product moment dan metode regresi linear berganda, yang terdiri atas variabel bebas kecemasan matematika $(X 1)$, digital storytelling (X2), dan variabel terikat math literacy $(Y)$. Menurut hasil analisis data membuktikan jika (1) ada hubungan dengan arah negatif serta derajat hubungan sedang antara kecemasan matematika terhadap math literacy, (2) terdapat hubungan dengan arah positif dan derajat hubungan yang kuat antara digital storytelling berhubungan terhadap math literacy, (3) terdapat hubungan positif antara kecemasan matematika dan digital storytelling terhadap math literacy sebesar $66 \%$. Untuk penelitian selanjutnya, agar peneliti tidak hanya menggunakan kuesioner untuk pengumpulan data, tetapi dapat membuat proyek dalam suatu kelas.
\end{abstract}

Kata kunci: Kecemasan Matematika, Digital Storytelling, Math Literacy, Pembelajaran Matematika

Copyright (c) 2021 Elsa Nabilah

$\triangle$ Corresponding author: Elsa Nabilah

Email Address: elsaanabilah@gmail.com (Jl. Tanah Merdeka No. 20 RT.11/RW.2, Jakarta Timur, DKI Jakarta)

Received 28 June 2021, Accepted 04 July 2021, Published 02 August 2021

\section{PENDAHULUAN}

Dalam melakukan pembelajaran matematika banyak siswa yang memiliki mindset atau pemikiran bahwa matematika merupakan pelajaran yang menakutkan. Hal tersebut dikarenakan suasana pembelajaran yang tercipta terlalu menegangkan sehingga dapat membuat minat belajar matematika pada siswa berkurang. Kebanyakan siswa mengira jika matematika ialah musuh mereka yang harus dihindari, hal tersebut terjadi dari adanya rasa takut siswa pada matematika, sehingga matematika menjadikan salah satu mata pelajaran yang tidak disukai oleh murid (Sirait, 2016). Padahal menurut (Octaviani, Indrawatiningsih, 
\& Afifah, 2021), matematika merupakan mata pelajaran yang tanpa kita sadari memiliki hubungan yang erat dengan banyak hal disekitar kita. Adanya rasa takut pada siswa yang terjadi secara terus-menerus saat melakukan pembelajaran matematika dapat menimbulkan rasa cemas yang menyebabkan adanya kecemasan matematika (Mathematics Anxiety).

Kecemasan matematika merupakan suatu keadaan atau situasi dimana siswa mengalami perasaan yang tidak nyaman, merasa takut dan cemas hingga dapat menyebabkan rasa sakit secara fisik saat berada dalam situasi yang berhubungan dengan matematika. Pemikiran dan sikap merupakan hal yang herhubungan dengan kecemasan matematika yang dapat menyebabnya berkurangnya kinerja seseorang ketika melakukan pekerjaan atau berada dalam keadaan yang berhubungan dengan matematika, hal tersebut dapat membuat seseorang merasa cemas dan menghindari matematika, sehingga dapat berdampak pada kemampuan pemecahan masalah matematika (Kargar, Tarmizi, \& Bayat, 2010). Kecemasan matematika merupakan keadaan psikologis yang berkaitan dengan kepercayaan yang dialami seseorang dimana terdapat ketakutan, rasa ingin menghindar, serta sangat mudah melupakan pembelajaran matematika dan hilangnya kepercayaan diri saat melakukan pembelajaran matematika, ketika seseorang tidak memiliki kepercayaan diri mereka akan menghindar dari segala situasi yang berhubungan dengan matematika, dengan melarikan diri atau menghindar dapat menyebabkan kepercayaan mereka bahwa mereka tidak mampu atau tidak bisa dalam matematika semakin kuat (Zakaria, Zain, Ahmad, \& Erlina, 2012). Menurut (Nabilah, Umam, Azhar, \& Purwanto, 2021), kecemasan matematika dapat digolongkan dalam kecemasan umum, yang memiliki komponen kognitif contohnya kekhawatiran seseorang saat melakukan pekerjaan yang memiliki kaitan dengan matematika dan komponen afektif contohnya perasaan takut, gugup, dan reaksi dari fisik yang tidak menyenangkan.

Munculnya kecemasan matematika dapat berasal diri sendiri yaitu kurangnya kepercayaan diri terhadap matematika atau memiliki pengalaman yang buruk dan trauma dengan matematika, kurang efektif dan inovatifnya kegiatan belajar mengajar dilaksanakan oleh guru serta suasana kegiatan belajar mengajar matematika yang tercipta terlalu menegangkan juga menjadi salah satu faktor munculnya kecemasan matematika pada siswa. Lingkungan yang memberikan pengalaman negatif serta guru yang memberi pengalaman yang negatif, rendahnya kepercayaan diri ketika sedang melakukan sesuatu yang berhubungan matematika dan kurangnya kemampuan kognitif siswa pada matematika merupakan faktor yang menyebabkan munculnya kecemasan matematika pada siswa (Aarnos \& Perkkilä, 2012). Salah satu contoh kecemasan yang terjadi dari faktor lingkungan adalah siswa merasa tidak percaya diri dan menganggap masih banyak yang memiliki kemampuan matematika yang lebih baik (Hastuti, Umam, Eclarin, \& Perbowo, 2021). Kecemasan matematika yang dialami siswa dapat menyebabkan terganggunya kemampuan kognitif siswa pada matematika khususnya dalam menyelesaikan permasalahan matematika karena siswa akan merasa terbebani bila mendapatkan tugas matematika (Namkung, Peng, \& Lin, 2019). Kecemasan matematika dapat terus bertambah seiiring dengan bertambahnya jenjang pendidikan seseorang karena semakin tinggi jenjang pendidikan, maka akan semakin rumit pula permasalahan matematika yang akan ditemukan, serta akan semakin kompleks juga penyelesaian masalahnya, sehingga dapat 
meningkatkan kecemasan matematika pada seseorang.

Dewasa ini kemajuan teknologi sangat berperan untuk memudahkan pendidik dalam membuat sebuah kelas virtual matematika dengan cara/media yang menarik dan tetap terjadi interaksi antara siswa dengan pendidik (Hastuti et al., 2021). Menurut (Kosiret, Indiyah, \& Wijayanti, 2021), pemilihan model pembelajaran yang sesuai akan membuat siswa menjadi aktif dalam mencari pengetahuan dan membangun konsep dari materi sehingga tercipta pembelajaran matematika yang efektif. Salah satu cara yang bisa dipakai untuk membuat suasana kegiatan belajar mengajar menjadi tidak menakutkan serta menyenangkan adalah dengan menggunakan digital storytelling sebagai model pembelajaran. Digital storytelling bisa diartikan sebagai suatu cara yang dipakai untuk membuat pembelajaran lebih menarik melalui cerita dengan penerapan teknologi berupa penampilan video, grafis atau audio dan lain-lain. Menurut (Razmi, Pourali, \& Nozad, 2014) digital storytelling adalah seni dongeng modern yang dimana seseorang dapat menganalisis seperti menentukan gambar, musik, narasi, dan suara secara bersamaan. Digital storytelling merupakan sebuah seni untuk bercerita yang menggunakan media, seperti komputer, kamera dan perekam audio yang berdurasi sekitar sepuluh menit dan dapat mengundang respon seseorang, sehingga dapat terjadi komunikasi yang interaktif (Gordon, 2011). Dalam pendidikan, digital storytelling dapat membantu siswa untuk berfikir kritis yaitu dengan pemberian tugas portofolio dalam proyek, digital storytelling dapat memperkuat keterampilan dalam meneliti, mengorganisasikan, menulis, mempresentasikan dan memecahkan masalah, dalam pembelajaran dengan digital storytelling guru berfungsi sabagai pembuat cerita yang berkaitan dengan pembelajaran kemudian mengintegrasikan multimedia kedalam kurikulum, sehingga dapat terciptanya konten yang mudah dipahami oleh siswa dan terbentuknya diskusi kelas (Lunce, 2007).

Dalam pembelajaran matematika penggunaan digital storytelling dapat menjadi salah satu cara untuk membuat siswa lebih nyaman selama pembelajaran, hal ini dikarenakan digital storytelling akan mempermudah siswa memahami materi. Salah satu contoh penerapan digital storytelling pada pembelajaran matematika ialah dengan memberikan video tentang kedudukan garis dan sudut. Pembelajaran dengan menggunakan video dapat menarik atensi siswa karena pembelajaran seperti ini tidak membosankan dan tidak membuat mereka merasa takut, kemudian siswa akan lebih mudah untuk mengerti teori itu karena penjelasan dilengkapi dengan ilustrasi yang jelas. Setelah menonton video siswa akan diberikan suatu masalah yang berkaitan dengan materi tersebut dan mendiskusikannya secara berkelompok, lalu mempresentasikan hasil diskusi kepada kelompok lain. Hal tersebut sejalan dengan (Julianingsih \& Krisnawati, 2019), dalam penelitian tersebut pembelajaran dilakukan menggunakan video yang berisi materi trigonometri, setelah dilakukan pemutaran video tersebut siswa diberi lembar kerja yang mencangkup masalah yang mesti didiskusikan secara berkelompok lalu mempresentasikannya kepada kelompok lain, menurut pengamatan peneliti pembelajaran menggunakan digital storytelling cukup baik karena terdapatnya perubahan tingkah laku pada siswa yang lebih baik dari sebelumnya. Dari penjelasan tersebut bisa disimpulkan jika pemakaian digital storytelling di kegiatan belajar mengajar dapat mengurangi rasa cemas atau takut siswa terhadap matematika. 
Menurut (Ikram, Purwanto, \& Parta, 2021), penalaran siswa dalam pembelajaran matematika memiliki kontribusi yang signifikan terhadap tercapainya hasil belajar siswa. Kemampuan menganalisis dan memahami bahasa matematika ialah salah satu kemampuan yang penting dalam kegiatan belajar mengajar matematika, dimana dalam matematika banyak melakukan analisis dalam menyelesaikan suatu masalah, dalam matematika kemampuan tersebut dinamakan Math literacy. Math literacy ialah kemampuan untuk mengerti, menganalisis, menyelesaikan masalah serta mempresentasikan matematika. Math literacy didasarkan pada teori yang berikatan dengan kehidupan sehari-hari, yang mengharuskan memecahkan masakah dan mengambil keputusan lalu mengkomunikasikan hasilnya, hal-hal tersebut menjadi landasan dari tujuan utama dari math literacy yaitu agar siswa dapat menemukan pembelajaran yang bermakna serta mengerti hubungan antara matematika dengan kehidupan sehari-hari (Niemi, Niu, Vivitsou, \& Li, 2018). Salah satu contoh bahwa siswa memperoleh pembelajaran matematika yang bermakna ialah mereka menyadari bahwa ilmu matematika sangat membantu kehidupannya sehari-hari, seperti materi program linear yang membantu dalam masalah jual beli.

Sejak menyebarnya COVID-19 di Indonesia, muncul kebijakan pemerintah tentang pembelajaran yang harus dilakukan secara online atau secara virtual. Kelas virtual merupakan suatu pembelajaran yang menggunakan media seperti video, yang dimana pembelajaran tidak terikat oleh waktu dan tidak dilakukan secara tatap muka (Nabilah et al., 2021). Dengan diberlakukannya pembelajaran kelas virtual membuat sebagian besar pembelajaran dilakukan melalui video pembelajaran yang merupakan salah satu contoh media dari digital storytelling. Hal tersebut tidak menutup kemungkinan terjadinya kecemasan matematika pada siswa karena banyak faktor yang dapat menyebabkan kecemasan matematika salah satunya lemahnya kemampuan kognitif siswa dalam memecahkan permasalahan matematika yang berhubungan dengan math literacy. Berdasarkan penjelasan tersebut, peneliti mencoba untuk mengerjakan pengkajian dengan judul "Hubungan Kecemasan Matematika dan Digital Storytelling Terhadap Math Literacy Dalam Pembelajaran Matematika Pada Kelas Virtual”.

Terdapat hipotesis yang dirumuskan sebagai berikut:

1. Hubungan antara kecemasan matematika dengan math literacy

$H 0=$ Tidak ada ikatan antara kecemasan matematika dengan math literacy

$H 1=$ Ada ikatan antara kecemasan matematika dengan math literay

2. Hubungan antara digital storytelling dengan math literacy

$H 0=$ Tidak ada ikatan antara digital storytelling dengan math literacy

$H 1$ = Ada ikatan antara digital storytelling dengan math literacy

3. Hubungan antara kecemasan matematika serta digital storytelling dengan math literacy

$H 0=$ Tidak terdapat hubungan antara kecemasan matematika serta digital storytelling dengan math literacy 
$H 1=$ Terdapat hubungan antara kecemasan matematika serta digital storytelling dengan math literacy

\section{METODE}

Dalam pengkajian ini memakai metode survey kuantitatif yang dimana pengambilan sampel dari suatu populasi ditetapkan sendiri oleh pengkaji. Sampel di pengkajian ini ialah siswa sekolah menengah pertama wilayah Jakarta, Bogor, Depok, Tangerang juga Bekasi (JABODETABEK) sejumlah 300 siswa. Instrumen penelitian yang digunakan ialah angket kuesioner yang mencangkup tentang pernyataan yang berikatan dengan kecemasan matematika, digital storytelling dan math literacy pada pembelajaran matematika yang diberikan melalui google form yang dilakukan secara online. Dalam instrumen penelitian tersebut menggunakan skala ukur yaitu rasio likert yang berisi atas 5 opsi jawaban, ialah (1) sangat tidak seperti saya, (2) tidak seperti saya, (3) agak seperti saya, (4) seperti saya, (5) sangat mirip dengan saya dan terdapat pernyataan yang menggunakan opsi jawaban sebagai berikut, (1) tidak pernah, (2) jarang, (3) kadang-kadang, (4) sering, (5) sangat sering. Penganalisisan data dilakukan menggunakan metode korelasi product moment dan metode regresi linear berganda dengan software SPSS versi 24 , yang dimana perlu dilakukan uji normalitas, uji linieritas dan uji multikolinearitas data terlebih dahulu. Metode korelasi product moment dilakukan untuk mengetahui tingkat keeratan dan arah hubungan antara kecemasan matematika $(X 1)$ dengan math literacy $(Y)$ dan digital storytelling $(X 2)$ dengan math literacy $(Y)$, sedangkan metode regresi linear berganda untuk mendeteksi hubungan secara bersamaan antara kecemasan matematika $(X 1)$, digital storytelling $(X 2)$ terhadap math literacy $(Y)$.

\section{HASIL DAN DISKUSI}

Penelitian dilakukan secara online dengan menyebarkan kuesioner penelitian yang berisi pernyataan yang berhubungan dengan kecemasan matematika, digital storytelling serta math literacy pada pembelajaran matematika pada kelas virtual yang diberikan melalui google form yang dilakukan oleh 300 siswa sekolah menengah pertama wilayah Jakarta, Bogor, Depok, Tangerang juga Bekasi (JABODETABEK). Berikut ialah pembahasan analisis data yang meliputi, hubungan kecemasan matematika terhadap math literacy, hubungan digital storytelling terhadap math literacy, dan hubungan kecemasan matematika dan digital storytelling terhadap math literacy.

\section{Uji Normalitas Data}

Uji normalitas data dikerjakan dengan memakai Software SPSS versi 24, yang dimana data bisa disebut berdistribusi normal jika nilai Sig atau substansial lebih besar dari 0.050 .

Tabel 1. Hasil Uji Normalitas Data

\begin{tabular}{|l|l|}
\hline & Unstandardiz ed Residual \\
\hline $\mathrm{N}$ & 300 \\
\hline Asymp. Sig (2-tailed) & .200 \\
\hline
\end{tabular}


Menurut hasil pengolahan data kedapatan nilai Sig atau signifikasi sejumlah 0.200, yang dimana $0.200>0.050$, maka bisa disimpulkan jika data itu berdistribusi normal.

\section{Uji Linearitas Data}

Sebelum dilakukan uji korelasi product moment dan uji regresi berganda, perlu dilakukan uji linearitas pada data yang bertujuan untuk mendeteksi hubungan antara variabel $(X)$ dan variabel $(Y)$.

Tabel 2. Hasil Uji Linearitas Data Kecemasan Matematika dengan Math Literacy

\begin{tabular}{|l|l|l|l|}
\hline \multicolumn{2}{|c|}{ Sig. } & \multicolumn{1}{c|}{ Sath Literacy $*$} \\
\cline { 2 - 4 } Kecemasan & Between Groups & (Combined) & .000 \\
\cline { 2 - 4 } & & Linearity & .000 \\
\cline { 2 - 4 } & & $\begin{array}{l}\text { Penyimpangan dari } \\
\text { Linearitas }\end{array}$ & .228 \\
\hline
\end{tabular}

Jika nilai Penyimpangan dari Linearitas lebih besar dari $0.050(>0.50)$ jadi data didefinisikan jika variabel-variabel tersebut memiliki hubungan yang linear. Menurut hasil uji linearitas, tampak nilai signifikasi deviation from linearity sebesar 0.228, yang dimana $0.228>0.050$, maka bisa disimpulkan jika ada hubungan yang linear antara kecemasan matematika $(X 1)$ dengan math literacy $(Y)$.

Tabel 3. Hasil Uji Linearitas Data Digital Storytelling dengan Math Literacy

\begin{tabular}{|c|c|c|c|}
\hline & & & \multirow[t]{2}{*}{ Sig. } \\
\hline \multirow{3}{*}{$\begin{array}{l}\text { Math Literacy* } \\
\text { Digital Storytelling }\end{array}$} & Between Groups & (Combined) & \\
\hline & & Linearity & .000 \\
\hline & & $\begin{array}{l}\text { Penyimpangan dari } \\
\text { Linearitas }\end{array}$ & .109 \\
\hline
\end{tabular}

Jika nilai Penyimpangan dari Linearitas lebih besar dari 0.050 (>0.50) jadi data didefinisikan jika variabel-variabel tersebut memiliki hubungan yang linear. Menurut hasil uji linearitas, didapatkan nilai signifikasi Penyimpangan dari Linearitas sejumlah 0.109, yang dimana $0.109>0.050$, maka bisa disimpulkan jika ada hubungan yang linear antara digital storytelling $(X 2)$ dengan math literacy $(Y)$.

\section{Uji Multikolinearitas}

Salah satu syarat untuk melakukan analisis regresi linear berganda ialah melakukan uji multikolinearitas dengan tujuan mendeteksi apakah terjadi hubungan yang kuat antar variabel independent. Menggunakan metode Tolerance dan VIF merupakan salah satu cara untuk mendeteksi gejala multikolinearitas.

Tabel 4. Hasil Uji Multikolinearitas Data Kecemasan Matematika dan Digital Storytelling terhadap Math

\begin{tabular}{|c|c|c|}
\hline & \multicolumn{2}{|c|}{ Literacy } \\
\hline & Tollerance & VIF \\
\hline (Constant) & & 1.063 \\
\hline Kecemasan Matematika & 0.941 & 1.063 \\
\hline Digital Storytelling & 0.941 & \\
\hline
\end{tabular}

\footnotetext{
Dependent Variable: Math Literacy
} 
Jika nilai Toleransi lebih besar dari 0.10 ( > 0.10), jadi tidak ada multikolinearitas, serta jika nilai VIF lebih kecil dari $10.00(<10.00)$, jadi tidak ada multikolinearitas. Menurut hasil uji multikolinearitas, didapatkan nilai Tolerance pada kecemasan matematika $(X 1)$ dan digital storytelling $(X 2)$ sebesar 0.941, yang dimana $0.941>0.10$, dan diperoleh nilai $V I F$ sejumlah 1.063 yang dimana $1.063<10.00$ maka bisa disimpulkan jika tidak terjadi multikolinearitas antara kecemasan matematika (X1) dan digital storytelling $(X 2)$ terhadap math literacy $(Y)$.

\section{Uji Hipotesa Data}

\section{Hubungan Kecemasan Matematika Terhadap Math Literacy}

Berdasarkan rumusan hipotesa pertama, maka dilakukan uji korelasi product moment untuk mendeteksi keeratan dan arah hubungan antara kecemasan matematika $(X 1)$ terhadap math literacy $(Y)$, dengan hasil sebagai berikut:

Tabel 5. Hasil Uji Korelasi Product Moment Hubungan Kecemasan Matematika Terhadap Math Literacy

\begin{tabular}{|c|c|c|c|}
\hline & & Kecemasan Matematika & Math Literacy \\
\hline \multirow{3}{*}{$\begin{array}{l}\text { Kecemasan } \\
\text { Matematika }\end{array}$} & Koleksi Pearson & 1 & -.451 \\
\hline & Sig. (2-tailed) & & .000 \\
\hline & $\mathrm{N}$ & 300 & 300 \\
\hline \multirow[t]{3}{*}{ Math Literacy } & Koleksi Pearson & -.451 & 1 \\
\hline & Sig. (2-tailed) & .000 & \\
\hline & $\mathrm{N}$ & 300 & 300 \\
\hline
\end{tabular}

Jika nilai substansial lebigh kecil dari $0.050(<0.050)$, maka bisa didefinisikan jika variabel tersebut berkorelasi atau terdapat hubungan. Kemudian unutk mengetahui derajat hubungan, dapat dilihat nilai Pearson Correlation dengan rubrik sebagai berikut:

Tabel 6. Tabel Nilai Koleksi Pearson

\begin{tabular}{|c|c|}
\hline Range & Kategori \\
\hline $0.00-0.20$ & tidak terdapat korelasi \\
\hline $0.21-0.40$ & korelasi lemah \\
\hline $0.41-0.60$ & korelasi sedang \\
\hline $0.61-0.80$ & korelasi kuat \\
\hline $0.81-1.00$ & korelasi sempurna \\
\hline
\end{tabular}

Menurut hasil pengujian data, diperoleh bahwa nilai signifikasi sejumlah 0.000 yang nilainya 0.000 $<0.050$ Jadi membuktikan jika terdapat hubungan antara kecemasan matematika dengan math literacy. Kemudian didapatkan nilai Koleksi Pearson sejumlah -0.451, sehingga bisa disimpulkan jika tingkat hubungan antara kecemasan matematika dengan math literacy termasuk dalam kategori sedang dengan arah hubungan negatif. Jadi, $H 0$ ditolak serta $H 1$ diterima, sampai bisa disimpulkan jika ada hubungan dengan arah hubungan negatif dengan derajat hubungan sedang antara kecemasan matematika terhadap math literacy di kegiatan belajar mengajar matematika.

Analisis data tersebut sejalan dengan (Gazali, 2017) bahwa kecemasan matematika terhadap kemampuan berpikir kritis di kegiatan belajar mengajar matematika tidak memiliki pengaruh secara langsung, yang dimana menurut (Abad, Wulandari, \& Azka, 2018) literasi matematika ialah kemampuan 
seseorang dalam merumuskan, memakai serta mengintrepretasikan matematika dalam sebagai konteks serta literasi matematika (Math Literacy) dipengaruhi oleh sebagian faktor salah satunya konsep diri atau tingkat perkembangan yang dimana terdalam kemampuan berpikir kritis. Hal ini sama dengan pengkajian ini dimana ketika siswa memiliki kecemasan matematika yang tinggi dalam pembelajaran matematika maka kemampuan literasi matematika (Math Literacy) siswa akan meningkat, begitu pun sebaliknya. Dengan penelitian ini maka terbukti jika ada keterkaitan yang negatif antara kecemasan matematika dengan math literacy dalam pembelajaran matematika.

\section{Hubungan Digital Storytelling Terhadap Math Literacy}

Berdasarkan rumusan hipotesa kedua, maka dilakukan uji korelasi product moment untuk mendeteksi keeratan dan arah hubungan antara digital storytelling $(X 2)$ terhadap math literacy $(Y)$, dengan hasil sebagai berikut:

Tabel 7. Hasil Uji Korelasi Product Moment Hubungan Digital Storytelling Terhadap Math Literacy

\begin{tabular}{|c|c|c|c|}
\hline & & Digital Storytelling & Math Literacy \\
\hline \multirow[t]{3}{*}{ Digital Storytelling } & Koleksi Pearson & 1 & .765 \\
\hline & Sig. (2-tailed) & & .000 \\
\hline & $\mathrm{N}$ & 300 & 300 \\
\hline \multirow[t]{3}{*}{ Math Literacy } & Koleksi Pearson & .765 & 1 \\
\hline & Sig. (2-tailed) & .000 & \\
\hline & $\mathrm{N}$ & 300 & 300 \\
\hline
\end{tabular}

Berdasarkan hasil pengujian data, diperoleh bahwa nilai signifikasi sejumlah 0.000 yang nilainya $0.000<0.050$ yang membuktikan jika ada hubungan antara digital storytelling dengan math literacy. Kemudian diperoleh nilai Koleksi Pearson sejumlah 0.765 (kategori bisa dilihat di Tabel 6.), sampai bisa disimpulkan jika tingkat hubungan antara digital storytelling dengan math literacy termasuk dalam kategori kuat dengan arah hubungannya positif. Maka, $H 0$ ditolak serta $H 1$ diterima, sampai bisa disimpulkan jika ada hubungan yang positif dengan derajat hubungan yang kuat antara digital storytelling berhubungan secara positif terhadap math literacy di kegiatan belajar mengajar matematika.

Analisis data tersebut sejalan dengan (Niemi et al., 2018) digital storytelling dapat memfasilitasi siswa untuk menjadi kompeten yang dimana digital storytelling terintegasi teknologi digital dengan pembelajaran matematika dan dapat mendorong siswa menjadi tekun dan senang ketika belajar dan juga digital storytelling menuntut siswa untuk mencari atau mengeksplor sendiri bagaimana menerapkan pengetahuan yang dimana hal ini berhubungan dengan math literacy. Hal ini sesuai dengan penelitian ini dimana ketika siswa memiliki minat yang rendah pada digital storytelling dalam pembelajaran matematika maka kemampuan dalam literasi matematika (Math Literacy) akan rendah pula, begitu pun sebaliknya. Dengan penelitian ini maka terbukti jika ada hubungan yang positif antara digital storytelling dengan math literacy dalam pembelajaran matematika.

\section{Hubungan Kecemasan Matematika dan Digital Storytelling Terhadap Math Literacy}

Berdasarkan rumusan hipotesa ketiga, maka dilakukan uji regresi linier berganda untuk mengetahui pengaruh simultan dan dengan nilai $\alpha$ pada tabel anova untuk mengetahui berapa persen pengaruh dari 
variabel $(X)$, yaitu kecemasan matematika $(X 1)$ dan digital storytelling $(X 2)$ terhadap math literacy $(Y)$, dengan hasil sebagai berikut:

Tabel 8. Hasil Uji Regresi Linier Berganda Hubungan Kecemasan Matematika dan Digital Storytelling

\begin{tabular}{|c|c|}
\hline \multicolumn{2}{|c|}{ Terhadap Math Literacy } \\
\hline Model & Koefisien \\
\hline (Constant) & 18.829 \\
\hline Kecemasan Matematika & -0.137 \\
\hline Digital Storytelling & 1.158 \\
\hline $\mathrm{R}$ & 0.812 \\
\hline$r^{2}$ & 0.660 \\
\hline
\end{tabular}

Dependent Variable: Math Literacy

Persamaan garis regresi ganda berdasarkan hasil olah data adalah sebagai berikut:

$$
Y=-0.137 X 1+1.158 X 2+18.829
$$

Persamaan di atas menunjukkan jika nilai koefisien pada kecemasan matematika adalah -0.137 , yang berarti jika nilai kecemasan matematika meningkat 1 poin maka terdapat penurunan pada nilai math literacy sebesar 0.137. Nilai koefisien sejumlah 1.158 yang artinya jika nilai digital storytelling menambah 1 poin maka terdapat peningkatan pula pada nilai math literacy sebesar 1.158. Berdasarkan hasil analisis regresi didapatkannilai koefisien determinasi $\left(r^{2}\right)$ sejumlah 0.660. Nilai $r^{2}$ tersebut menunjukan bahwa pengaruh kecemasan matematika dan digital storytelling terhadap math literacy sebesar 66\%, sedangkan 34\% lainnya dipengaruhi oleh variabel lain diluar varibel tersebut. Kemudian berdasarkan tabel anova yang diperoleh bahwa nilai $\alpha=0.000$ yang dimana $0.000<0.050$, maka $H 0$ ditolak serta $H 1$ diterima, sampai bisa disimpulkan jika ada hubungan positif antara kecemasan matematika serta digital storytelling terhadap math literacy dalam pembelajaran matematika.

Menurut hasil analisis data, didapatkan jika ada hubungan yang positif antara kecemasan matematika dan digital storytelling terhadap math literacy. Ketika kecemasan matematika diuji korelasi dengan math literacy menghasilkan hubungan yang negatif, namun ketika diuji bersamaan dengan digital storytelling akan menghasilkan hubungan yang positif terhadap math literacy. Hal tersebut dapat terjadi karena tingginya kecemasan matematika yang dialami pada siswa yang berhubungan dengan digital storytelling sehingga dapat mempengaruhi math literacy dalam pembelajaran matematika pada kelas virtual. Pernyataan tersebut sejalan dengan (Pradana, Sholikhah, Maharani, \& Kholid, 2020) yang menyimpulkan bahwa salah satu pendukung literasi matematika siswa pada pembelajaran kelas virtual adalah penggunaan media digital yang mampu menyajikan konsep abstrak dalam konsep konkret. Dari pernyataan tersebut dapat dikatakan bahwa media digital berpengaruh dalam literasi matematika siswa pada kelas virtual, yg dimana selaras dengan penelitian ini dengan media digital yang digunakan adalah digital storytelling dan dihubungkan dengan kecemasan matematika siswa yang berkesimpulan bahwa adanya hubungan antara kecemasan matematika dan digital storytelling terhadap math literacy dalam pembelajaran matematika pada kelas virtual. 


\section{KESIMPULAN}

Menurut hasil pengkajian membuktikan jika ada hubungan dengan arah hubungan negatif dan derajat hubungan yang sedang antara kecemasan matematika terhadap math literacy dalam pembelajaran matematika pada kelas virtual, yang berarti bertambah tinggi tingkat kecemasan matematika pada siswa jadi akan bertambah rendah kemampuan math literacy siswa pada pembelajaran matematika dan begitu pula sebaliknya. Kemudian terdapat hubungan dengan arah hubungan yang positif dan derajat hubungan yang kuat antara digital storytelling terhadap math literacy dalam pembelajaran matematika pada kelas virtual, yang berarti semakin tinggi minat siswa pada digital storytelling maka akan semakin tinggi kemampuan math literacy siswa pembelajaran matematika dan begitu pula sebaliknya. Lalu terdapat pengaruh kecemasan matematika dan digital storytelling terhadap math literacy sebesar 66\%, maka terdapat hubungan antara kecemasan matematika dan digital storytelling dengan math literacy dalam pembelajaran matematika dengan arah hubungan yang positif, yang berarti bertambah tinggi tingkat kecemasan siswa dan minat siswa pada digital storytelling maka akan bertambah tinggi juga kemampuan math literacy siswa dalam pembelajaran matematika pada kelas virtual.

Berdasarkan analisis peneliti, diharapkan pendidik dapat membuat suasana pembelajaran matematika menjadi lebih menyenangkan agar siswa tidak memiliki rasa takut ketika mengikuti pembelajaran matematika yang dapat menyebabkan munculnya kecemasan matematika pada siswa. Menciptakan pembelajaran matematika yang inovatif juga diperlukan terlebih pada situasi saat ini yang mengharuskan melakukan pembelajaran secara virtual (online), sehingga penggunaan digital storytelling dan minat dalam math literacy sangat penting dalam menunjang pembelajaran matematika.

\section{UCAPAN TERIMA KASIH}

Segala puji bagi Allah SWT. Terima kasih kepada orang tua saya yang terus mendukung serta mendoakan saya. Terima kasih kepada pembimbing yang memimpin penyusunan jurnal ini. Terima kasih kepada ketua program penelitian dan anggota program penelitian yang telah memberikan saran. Terima kasih kepada responden yang sudah mengikuti dalam pengkajian ini. Terima kasih kepada teman-teman beserta kenalan yang selalu memberikan semangat serta dukungan selama penyusunan jurnal ini.

\section{REFERENSI}

Aarnos, E., \& Perkkilä, P. (2012). Early Signs of Mathematics Anxiety? Procedia - Social and Behavioral Sciences, 46(2003), 1495-1499. https://doi.org/10.1016/j.sbspro.2012.05.328

Abad, M. K., Wulandari, E., \& Azka, R. (2018). Menyambut Pisa 2018: Pengembangan Literasi Matematika Untuk. De Fermat:Jurnal Pendidikan Matematika, 1(1), 31-38. Retrieved from https://jurnal.pmat.uniba-bpn.ac.id/index.php/DEFERMAT/article/download/14/8

Gazali, M. (2017). Pengaruh Bentuk Tes Formatif Dan Kompetensi Guru Terhadap Hasil Belajar Fisika. Jurnal Penelitian Pendidikan Dan Penilaian Pendidikan, 2(1), 140-157. https://doi.org/10.22236/JPPP 
Gordon, C. (2011). Digital Storytelling in the Classroom: Three Case Studies. Arizona State University, (December), 201.

Hastuti, E. S., Eclarin, L., \& Dalam, K. K. S. (2021). Kecemasan Siswa Sekolah Menengah Pertama Menyelesaikan Masalah SPLDV Pada Kelas Virtual Dalam. 8435(1).

Ikram, M., Purwanto, \& Parta, I. N. (2021). Analysis of The Occurrence of Reversible Reasoning for Inverse Cases: A Case Study on The Subject Adjie. International Journal of Progressive Mathematics Education, 1(1), 1-15.

Julianingsih, D., \& Krisnawati, E. (2019). Pemanfaatan Video digital Storytelling dalam Pembelajaran Trigonometri untuk pemerolehan Kecakapan Intelektual Siswa. SNITER (Seminar Nasional Ilmu Terapan), 1-8.

Kargar, M., Tarmizi, R. A., \& Bayat, S. (2010). Relationship between mathematical thinking, mathematics anxiety and mathematics attitudes among university students. Procedia - Social and Behavioral Sciences, 8, 537-542. https://doi.org/10.1016/j.sbspro.2010.12.074

Kosiret, A., Indiyah, F. H., \& Wijayanti, D. A. (2021). The Use of Generative Learning Model in Improving Students' Understanding of Mathematical Concepts of Al-Azhar 19 Islamic High School. International Journal of Progressive Mathematics Education, 1(1), 16-26.

Lunce, B. C. (2007). Digital Storytelling as an Educational Tool. Inidiana Libriaries, 30(1), 77-80.

Nabilah, E., Umam, K., Azhar, E., \& Purwanto, S. E. (2021). Kecemasan Siswa Dalam Menyelesaikan Masalah Modelling Matematika Pada Praktek Kelas Virtual. Internatioinal Journal of Progressive Mathematics Education, 1(1), 41-60.

Namkung, J. M., Peng, P., \& Lin, X. (2019). The Relation Between Mathematics Anxiety and Mathematics Performance Among School-Aged Students: A Meta-Analysis. In Review of Educational Research (Vol. 89). https://doi.org/10.3102/0034654319843494

Niemi, H., Niu, S., Vivitsou, M., \& Li, B. (2018). Digital storytelling for twenty-first-century competencies with math literacy and student engagement in China and Finland. Contemporary Educational Technology, 9(4), 331-353. https://doi.org/10.30935/cet.470999

Octaviani, K. D., Indrawatiningsih, N., \& Afifah, A. (2021). Kemampuan Visualisasi Spasial Siswa Dalam Memecahkan Masalah Geometri Bangun Ruang Sisi Datar Kemampuan Visualisasi Spasial Siswa Dalam Memecahkan Masalah Geometri Bangun Ruang Sisi Datar. International Journal of Progressive Mathematics Education, 1(1), 27-40.

Pradana, L. N., Sholikhah, O. H., Maharani, S., \& Kholid, M. N. (2020). Virtual mathematics kits (VMK): Connecting digital media to mathematical literacy. International Journal of Emerging Technologies in Learning, (3), 234-241. https://doi.org/10.3991/ijet.v15i03.11674

Razmi, M., Pourali, S., \& Nozad, S. (2014). Digital Storytelling in EFL Classroom (Oral Presentation of the Story): A Pathway to Improve Oral Production. Procedia - Social and Behavioral Sciences, 98(2011), 1541-1544. https://doi.org/10.1016/j.sbspro.2014.03.576

Sirait, E. D. (2016). Pengaruh Minat Belajar Terhadap Prestasi Belajar Matematika. Formatif: Jurnal Ilmiah 
Hubungan Kecemasan Matematika dan Digital Storytelling Terhadap Math Literacy Pada Siswa Sekolah Menengah Pertama dalam Pembelajaran Matematika Pada Kelas Virtual, Elsa Nabilah

Pendidikan MIPA, 6(1), 35-43. https://doi.org/10.30998/formatif.v6i1.750

Zakaria, E., Zain, N. M., Ahmad, N. A., \& Erlina, A. (2012). Mathematics anxiety and achievement among secondary school students. American Journal of Applied Sciences, 9(11), 1828-1832. https://doi.org/10.3844/ajassp.2012.1828.1832. 